\title{
Percoll-gradient separation of Leydig cells from postnatal rat testes
}

\author{
G. P. Risbridger and D. M. de Kretser \\ Department of Anatomy, Monash University, Clayton, Victoria 3168, Australia
}

\begin{abstract}
Summary. The characteristics of the fetal and adult populations of Leydig cells from postnatal rat testes were compared by Percoll gradient centrifugation. A single peak of hCG binding, due to the presence of fetal Leydig cells, was obtained after purification of intertubular cells from 8-day-old animals. Two peaks of specific hCG binding were obtained after purification of intertubular cells from 15-day-old rats: it was confirmed by autoradiographic techniques that the hCG was bound by adult-like Leydig cells in one peak and fetal Leydig cells in the other. Similarly, intertubular cell preparations from 21 - and 25-day-old rats resolved into two peaks of hCG binding; adult-like Leydig cells were observed in the first peak, but fetal Leydig cells were rarely observed in the second of these peaks. These results demonstrate the separation of two Leydig cell populations from intertubular cells obtained from animals aged up to 15 days. Thereafter the pattern of the hCG binding profile is similar but is not due to the presence of the same cell types. Therefore these results emphasize the necessity for morphological identification of cell types to permit the correct interpretation of the corresponding biochemical data.
\end{abstract}

\section{Introduction}

There are two growth phases of activity of testicular intertubular tissue in the rat. The first phase is during fetal life when the androgens secreted by the fetal generation of Leydig cells are required for sexual differentiation of the male fetus (Roosen-Runge \& Anderson, 1959). These cells are believed to regress postnatally because the second phase of Leydig cell development occurs during the 2 nd and 3rd week of life (Roosen-Runge \& Anderson, 1959; Lording \& de Kretser, 1972). Fetal Leydig cells can be distinguished from adult Leydig cells by morphological criteria as they contain abundant lipid inclusions and the mitochondrial cristae are tubular (Lording \& de Kretser, 1972).

Several studies have demonstrated that cells obtained from the intertubular tissue of adult mouse or rat testes include two populations of cells which bind hCG, and that these can be separated by centrifugation through gradients of Percoll or Metrizamide (Payne, Downing \& Wong, 1980; Cooke, Magee-Brown, Golding \& Dix, 1981; Dehejia, Nozu, Catt \& Dufau, 1982; Kerr, Robertson \& de Kretser, 1985). The aim of this study was to utilize this procedure to separate the two populations of Leydig cells from postnatal rat testes.

\section{Materials and Methods}

Isolation of interstitial cells. Testes were removed from 5-50 rats, the number depending on their ages which ranged from $8,12,15,17,21,25$ to $70-90$ (adult) days. The testes were decapsulated and l-5 g tissue were incubated in $12 \mathrm{ml}$ Hanks Balanced Salt Solution (HBSS: Flow Laboratories, McLean VA, USA) containing $0.25 \mathrm{mg}$ collagenase $/ \mathrm{ml}$. The buffer (HBSS) used throughout the preparation contained $20 \mathrm{~mm}-$ Hepes and $0.1 \% \mathrm{BSA}$. After incubation of the testes for $15 \mathrm{~min}$ at $37^{\circ} \mathrm{C}$ in a water bath shaking at $100 \mathrm{cycles} / \mathrm{min}$, the solution was filtered through nylon gauze and 


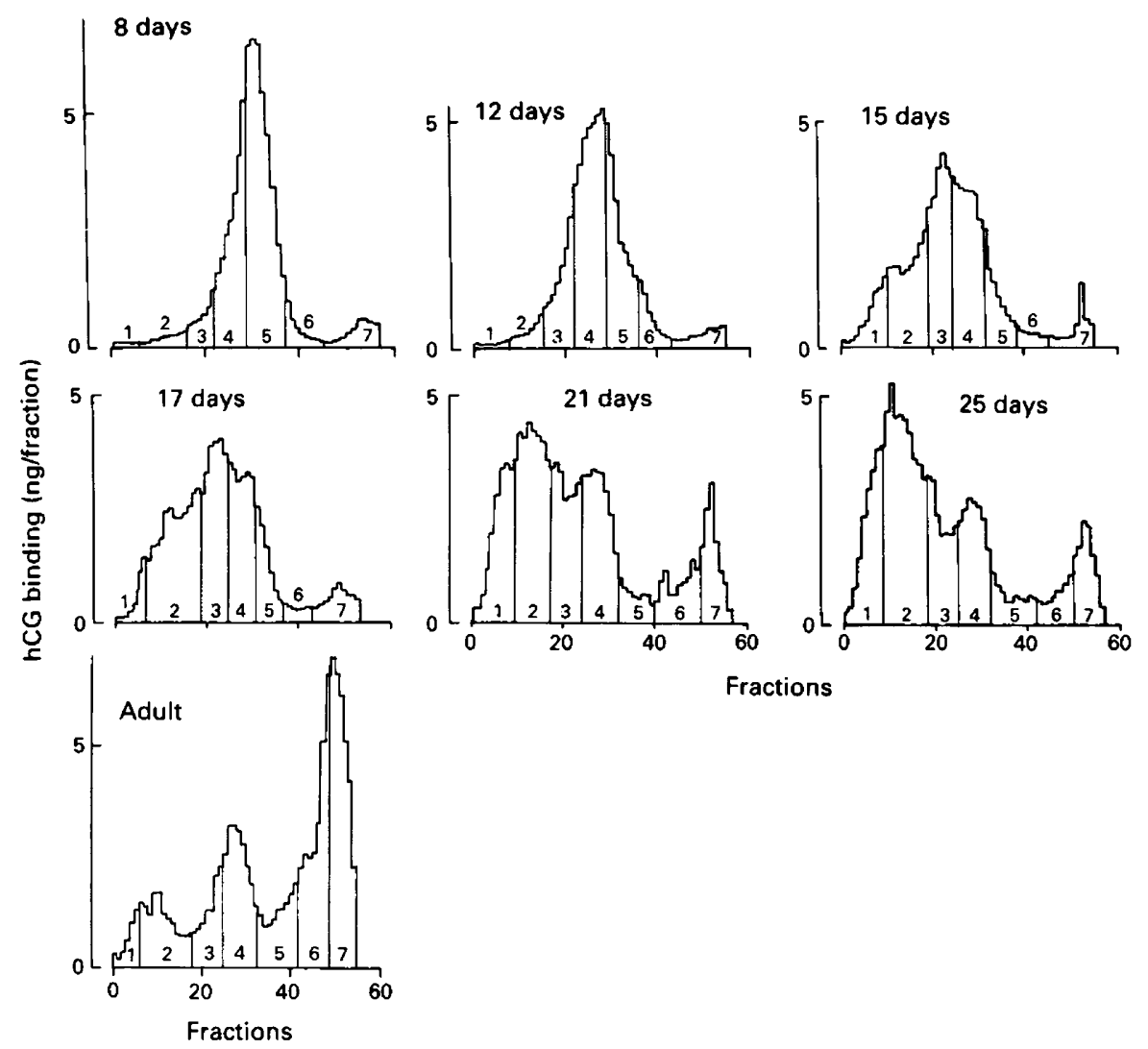

Fig. 1. Binding profiles of hCG obtained after Percoll gradient centrifugation of intertubular cells from rats of various ages. The numbers 1-7 indicate the gradient fractions (Fractions 1-7).

washed with two volumes of buffer. The filtrate was centrifuged for $5 \mathrm{~min}$ at $120 \mathrm{~g}$, and the cells washed twice more and resuspended in HBSS. To obtain the hCG binding profile the cells were incubated for $60 \mathrm{~min}$ with ${ }^{125} \mathrm{I}$-labelled hCG $\left(10^{6}\right.$ c.p.m.; sp. act. $\left.20 \mu \mathrm{Ci} / \mu \mathrm{g}\right)$ and washed free of unbound tracer-hormone before centrifugation through Percoll gradients. HCG (CR 121) was iodinated by a mild chloramine-T procedure, as detailed by Risbridger, Kerr \& de Kretser (1981). Non-specific binding was determined in an identical incubation in the presence of $500 \mathrm{i} . \mathrm{u}$. hCG (Pregnyl: Organon, UK).

Preparation of Percoll gradients and separation of cells. Linear gradients of $0-77 \%$ Percoll (Pharmacia, Uppsala, Sweden) were prepared as described by Cooke et al. (1981) with the aid of a peristaltic pump. The crude intertubular cell preparation was applied to the gradient which was then centrifuged for $20 \mathrm{~min}$ at $800 \mathrm{~g}$. The gradient was fractionated and the binding of hCG to each fraction was determined by counting in a gamma spectrometer. The refractive index (RI) of an aliquant of every 5 th fraction was determined.

Microscopy and autoradiography. The fractions of the gradient were pooled according to their refractive index to yield 7 major fractions: Fraction 1, RI (specific gravity) > 1.3450 (> 1.0742); Fraction 2, RI 1.3430-1.3450 (1.0591-1.0742); Fraction 3, RI 1.3420-3430 (1.0515-1.0591); Fraction 4, RI 1.3410-1.3420 (1.0440-1.0515); Fraction 5, RI 1.3400-1.3410 (1.0365-1.0440); Fraction 6, RI 1.3390-1.3400 (1.0290-1.0365); Fraction 7, RI 1.3380-1.3390 (1.0215-1.0290), as previously 


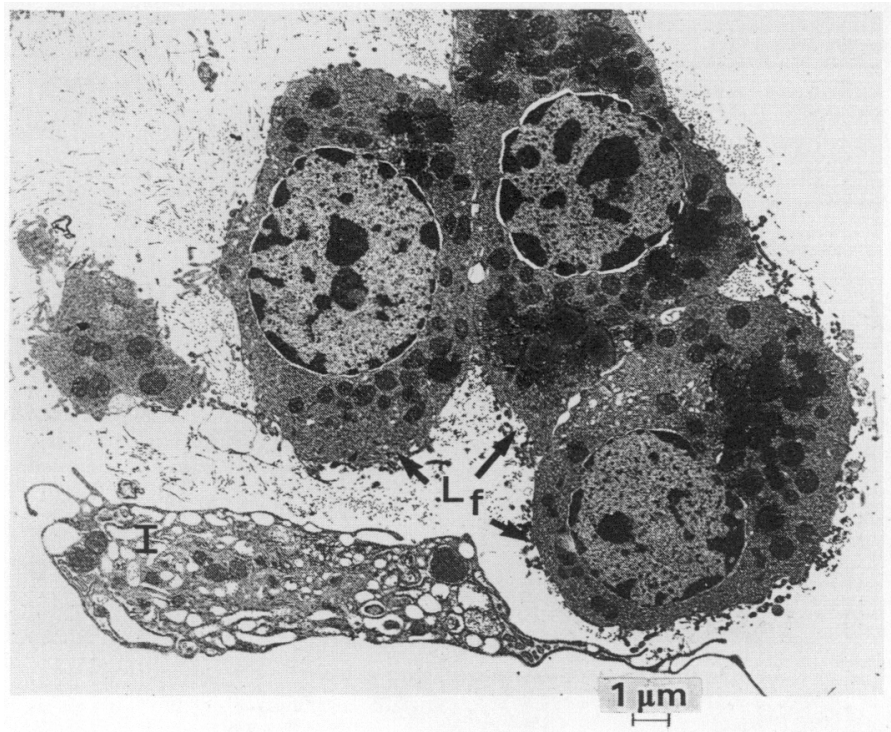

Fig. 2. Cell types present in the peak of hCG binding located over Fractions 4-5 after Percoll gradient centrifugation of intertubular cells from 8 -day-old rats. $\mathrm{L}_{\mathrm{f}}=$ fetal Leydig cell; $\mathrm{I}=$ indeterminate connective tissue cell.

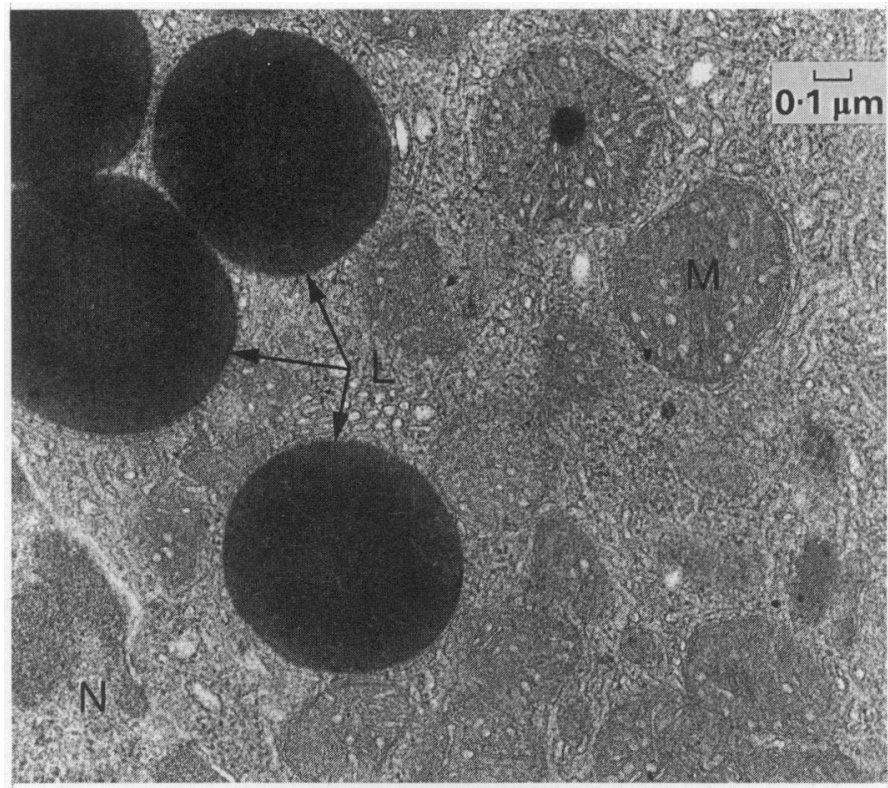

Fig. 3. Electron micrograph of fetal Leydig cell present in Fractions $4+5$ after Percoll gradient centrifugation of intertubular cells from 8-day-old rats. $\mathrm{L}=$ lipid; $\mathrm{M}=$ mitochondria: $\mathrm{N}=$ nucleus.

described (Laws, Wreford \& de Kretser, 1985). The major fractions from Percoll gradient purification of intertubular cells prepared from 8-, 15- and 25-day-old and adult animals were centrifuged, washed twice in HBSS and fixed in cacodylate-buffered glutaraldehyde. The pellets were then post-fixed in osmium tetroxide, processed and embedded in Epon-Araldite. Sections $(1 \mu \mathrm{m})$ 


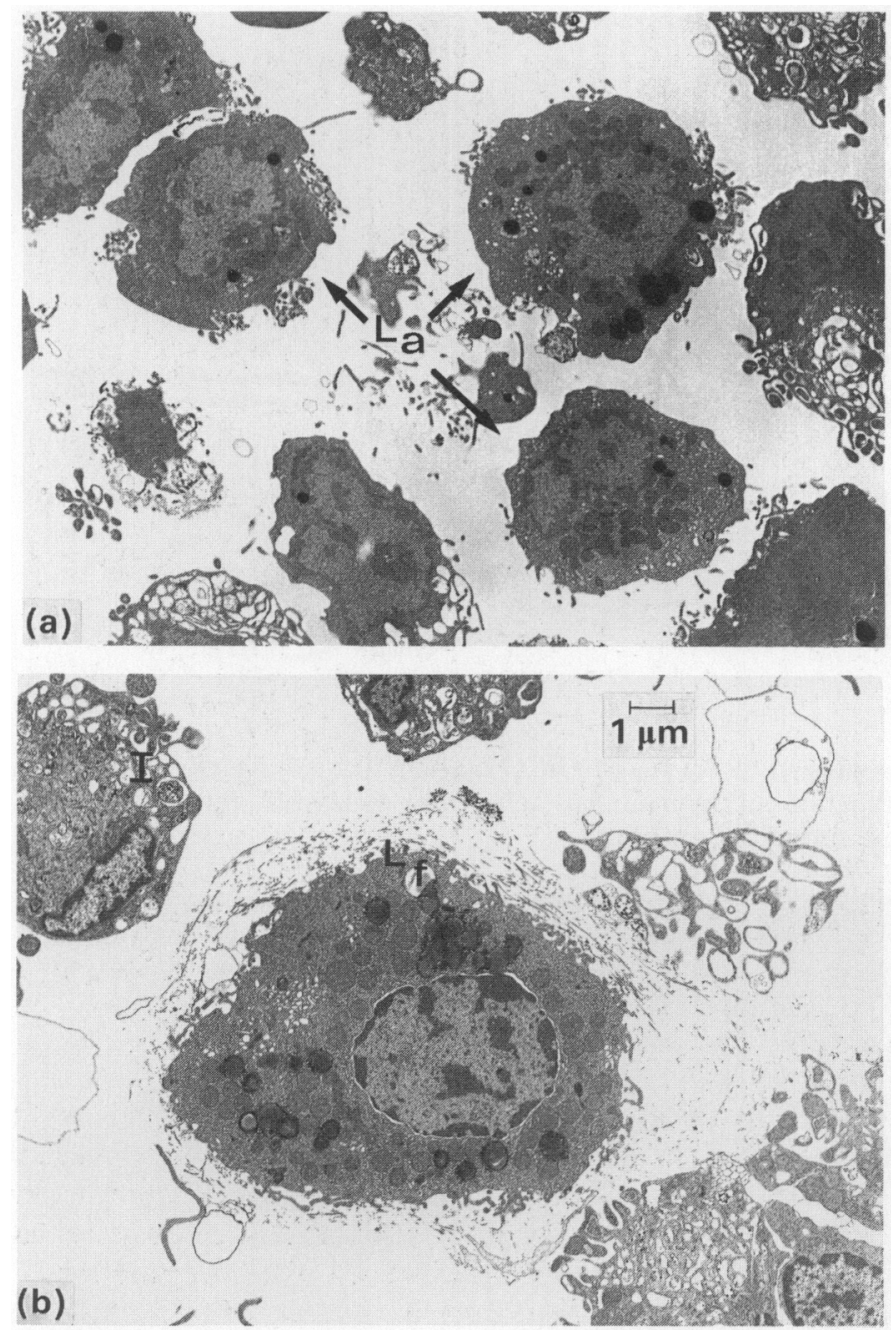

Fig. 4. Cell types present after Percoll gradient centrifugation of intertubular cells prepared from 15-day-old animals: (a) cells in Fractions $1+2$; (b) cells in Fractions 3-5. $\mathbf{L}_{\mathrm{a}}=$ adult-like Leydig cell; $\mathrm{L}_{\mathrm{f}}=$ fetal Leydig cell.

were stained with toluidine blue and examined with a Leitz Orthoplan light microscope. Thin sections stained with lead citrate were examined with a Jeol $100 \mathrm{~S}$ microscope.

The localization of the bound ${ }^{125} \mathrm{I}$-labelled hCG was determined by light microscope autoradiography. Pellets of cells obtained from each major fraction after Percoll gradient centrifugation of intertubular cells from 15- or 25-day-old animals were fixed and embedded. Sections ( $1 \mu \mathrm{m})$ were mounted on glass slides and processed for autoradiography. The slides were dipped in Ilford L4 nuclear emulsion and exposed for 5 weeks at $4{ }^{\circ} \mathrm{C}$. After developing, the slides were stained with toluidine blue and examined by light microscopy.

\section{Results}

\section{Binding profiles of $h C G$}

The profile of ${ }^{125}$ I-labelled hCG binding in fractions collected after Percoll gradient centrifugation of interstitial cells prepared from an adult rat (Fig. 1) is similar to that reported by Payne 


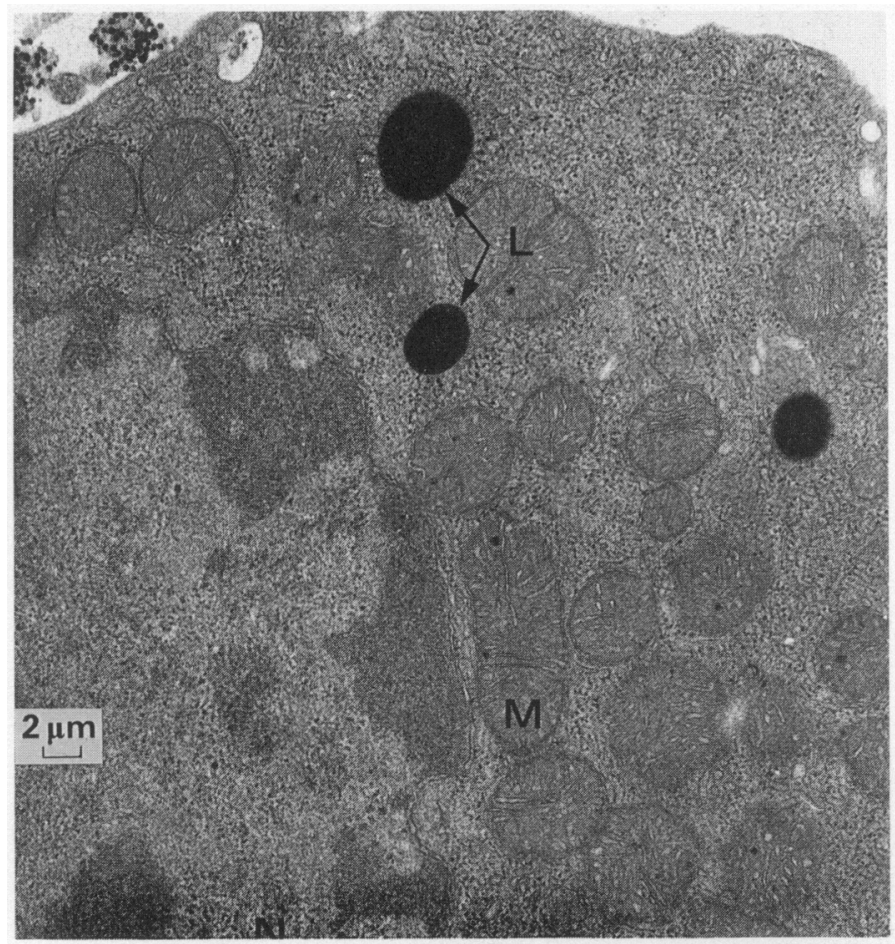

Fig. 5. Electron micrograph of adult-like Leydig cells identified in Fractions $1+2$ of the gradient after purification of cells from 15-day-old rats. $\mathrm{G}=$ germ cell; $\mathbf{L}=$ lipid; $\mathrm{M}=$ mitochondria; $\mathrm{N}=$ nucleus.

et al. (1980) and shows two peaks of specific hCG binding (Fractions $1+2$ and Fractions $3+4)$. Damaged cells, membranes and germ cells were present in Fractions 5-7. Examination of the hCG binding profiles of interstitial cells obtained during postnatal development revealed significant changes (Fig. 1). From the intertubular cells of 8-day-old animals there was a single peak of specific hCG-binding located over Fractions 4 and 5. Purification of cell preparations from 12-, 15- and 17-day-old rats revealed a gradual shift in the specific binding of ${ }^{125}$ I-labelled hCG towards the regions corresponding to Fractions 1,2 and 3. The binding of $\mathrm{hCG}$ to the intertubular cells from 21 - and 25-day-old animals was located over two peaks, illustrating a profile which was very similar to that of the adult intertubular cell preparations.

\section{Histology}

The single peak of hCG binding located in Fractions $4+5$ after centrifugation of intertubular cells from 8-day-old rats contained fetal Leydig cells which were identified by their abundant lipid inclusions and mitochondria with tubular cristae (Lording \& de Kretser, 1972) (Figs 2 \& 3). Immature Sertoli cells were also identified in these fractions, together with indeterminate connective tissue cells. This latter cell type included fibroblasts and endothelial cells which were identified as circular profiles because their cytoplasmic processes round up during the isolation procedure and the cells assume a spherical configuration (Kerr et al., 1985; Laws et al., 1985). The Sertoli cells were identified by their irregularly shaped nuclei and mitochondria with dilated cristae. Macrophages stained more lightly with toluidine blue than did Leydig cells and contained large vacuoles.

Fractions 1 and 2 obtained after centrifugation of intertubular cells from 15-day-old rats contained Leydig cells which more closely resembled those present in the adult animal (see Figs $4 a \&$ 


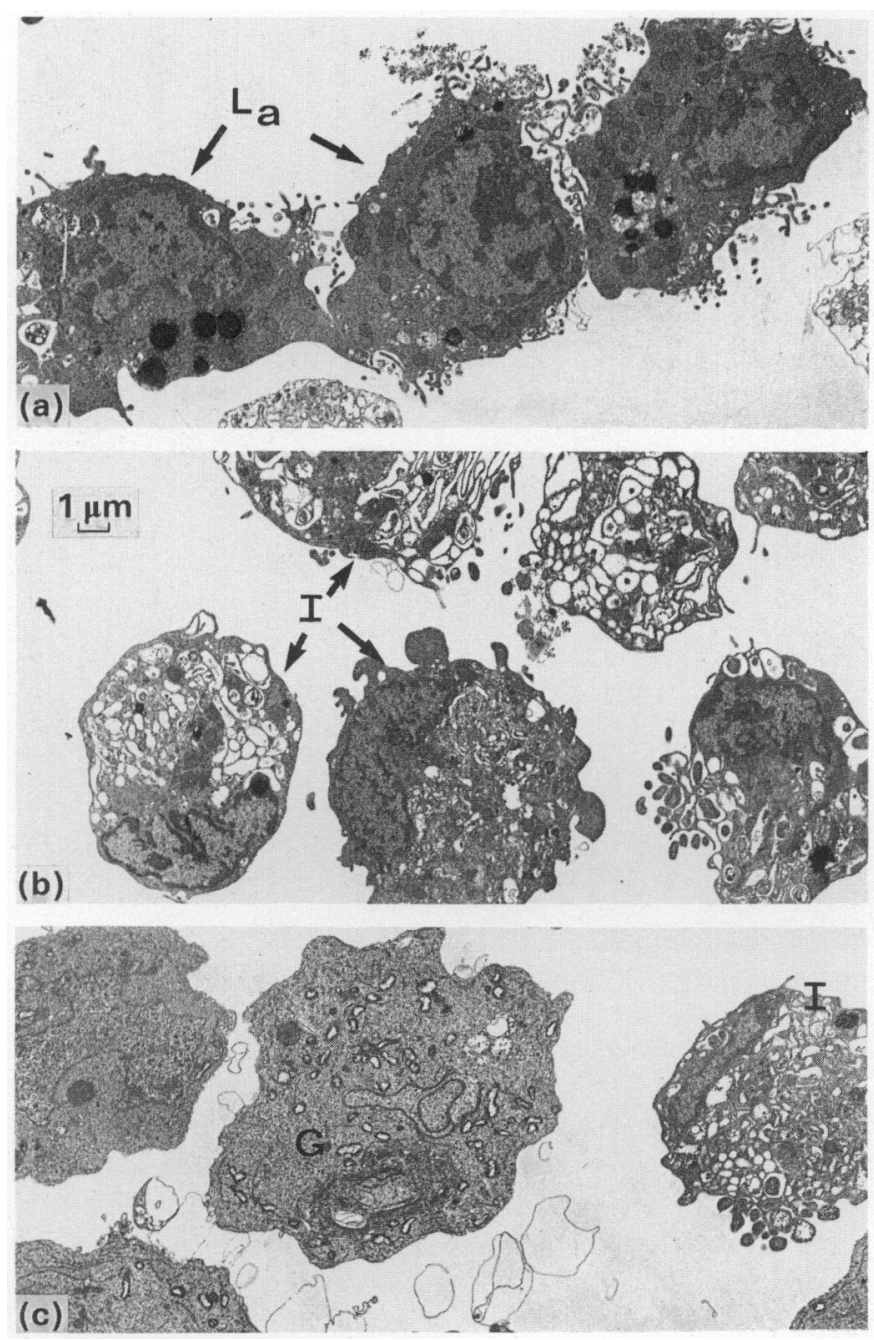

Fig. 6. Cell types present after purification of intertubular cells from 25-day-old animals: (a) cells in Fractions $1+2$; (b) (c) cells in Fractions $3-5 . \mathrm{L}_{\mathrm{a}}=$ adult-like Leydig cell; $\mathrm{I}=$ indeterminate connective tissue cell.

5). Fetal Leydig cells were clearly identified in Fractions 3-5 (Fig. 4b), together with indeterminate connective tissue cells, Sertoli cells and a few spermatogonia (not shown).

Adult-like Leydig cells were identified in Fractions $1+2$ after centrifugation of intertubular cells from 25-day-old rats (Fig. 6a). Fetal Leydig cells were no longer observed in Fractions 3-5 but indeterminate connective tissue cells, Sertoli and germ cells were present (Figs 6b \& 6c).

\section{Autoradiography}

The specific binding of ${ }^{125} \mathrm{I}$-labelled hCG to fetal Leydig cells in Fractions 3-5 and adult-like Leydig cells in Fractions $1+2$ was confirmed by autoradiography. The localization of ${ }^{125}$ I-labelled hCG over some indeterminate connective tissue cells in Fractions $3-5$ was observed after centrifugation of intertubular cells from 15- and 20-day-old animals (Fig. 7). The grain counts over Leydig cells in Fractions $1+2$ of gradients from 20-day-old animals confirmed specific binding $(7.66 \pm 3.24$ specific vs $0.78 \pm 1.28$ non-specific grains per cell (mean \pm s.d., $n=50$, 


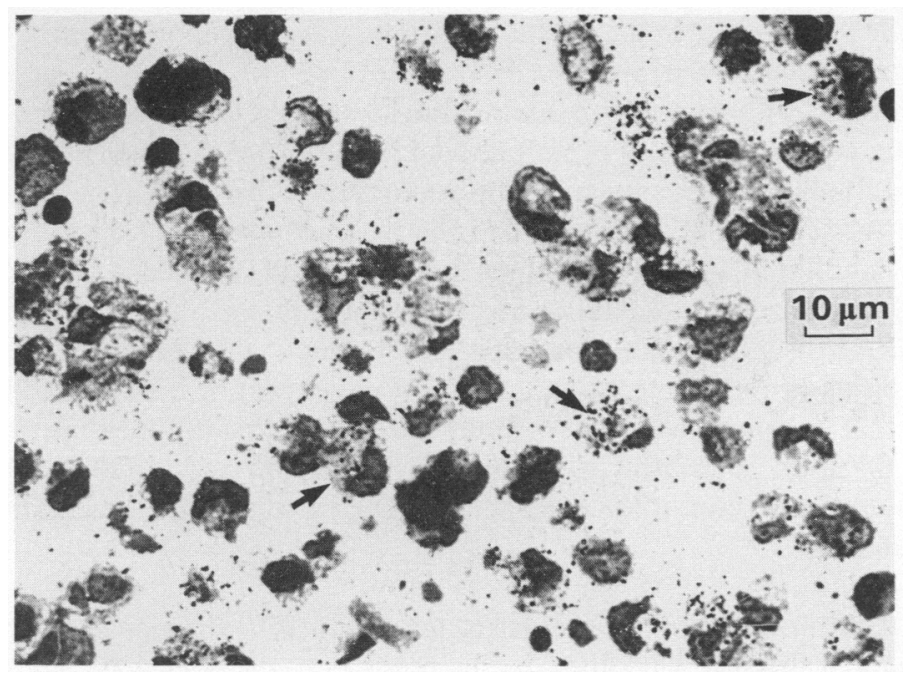

Fig. 7. The localization of ${ }^{125} \mathrm{I}$-labelled hCG (indicated by arrows) on some mesenchymal cells present in Fractions 3-5 after Percoll gradient centrifugation of intertubular cells from 20-day-old animals.

$P<0.01)$ ). The grain counts over mesenchymal cells in Fractions $3-5$ also demonstrated significant specific binding (3.88 \pm 2.73 specific vs $0.15 \pm 0.36$ non-specific grains per cell (mean \pm s.d., $n=60, P<0.01)$ ).

\section{Discussion}

These results demonstrate that there are striking differences in the flotation densities of fetal and adult Leydig cells, which result in their location in different regions of $0-77 \%$ Percoll density gradients. This difference in flotation density may be principally due to the high lipid content which characterizes fetal Leydig cells (Lording \& de Kretser, 1972). However, the position of fetal Leydig cells on Percoll gradients is the same as that in which the second peak of hCG binding occurs after fractionation of interstitial cells from adult male rats. This peak of binding was thought to be due to a second type of Leydig cell (Payne et al., 1980; Cooke et al., 1981) or to damaged Leydig cells (Aldred \& Cooke, 1982; Dehejia et al., 1982). However, detailed morphometric studies have shown that this fraction contains mesenchymal cells and fragments of Leydig cell cytoplasm (Laws et al., 1985). Therefore, the results of the present study demonstrate that a peak of hCG binding located in a specific fraction of a Percoll density gradient cannot be assumed to be due to the presence of the same cell type when cell preparations are fractionated from testes of animals in different physiological states.

It is not possible from this study to determine whether the adult-type Leydig cells that are located in Fractions $1+2$ after centrifugation of interstitial cells from 15-25-day-old animals arise by alteration of fetal Leydig cells or by differentiation from a precursor cell, such as a mesenchymal cell. A detailed morphological study (S. Mendis, G. Risbridger \& D. de Kretser, unpublished observations) has demonstrated that the number of fetal Leydig cells does not change up to 20 days of age, although their size decreases after 15 days. However, these cells do not show any morphological signs of degeneration such as pycnotic nuclei or vacuolation of the cytoplasm, and therefore it is possible that they may contribute to the pool of adult-type Leydig cells.

Alternatively, the adult-type Leydig cells may differentiate from a stem cell or precursor, an hypothesis which has been proposed previously, but for which there is no definitive evidence (for reviews, see Hooker, 1948; Christensen, 1975). Evidence for this hypothesis is obtained from the 
observation that the prepubertal human testis responds to hCG stimulation at a time when adult Leydig cells are absent and mesenchymal cells are identified in the intertubular tissue (Rivarola, Bergada \& Cullen, 1970), although a more recent study by Prince (1984) has described the presence of immature Leydig cells in the testes of prepubertal boys. However, after fractionation of interstitial cells from adult mice, it was shown by autoradiography that hCG was bound to an indeterminate connective tissue cell that was similar to the mesenchymal cell (Kerr et al., 1985). In the present study, the binding of hCG in Fractions 3-5 from interstitial cells of 25-day-old animals, which was not due to the presence of fetal Leydig cells, suggests that a mesenchymal cell type found therein may bind hCG. The theory is supported by the finding that hCG bound specifically to some mesenchymal cells; this is a characteristic that one would expect of a Leydig cell precursor. It is therefore possible that mesenchymal cells type may diffrentiate to adult Leydig cells and may alone be responsible for the adult generation of Leydig cells; or they may add to the pool of adult Leydig cells which arise by an alteration of the existing fetal Leydig cells. Further studies are required to explore these possibilities.

We thank Ms J. Muir and Mrs R. Mayberry for technical assistance and Dr A. Jackson for advice and discussion. The study was supported by funds from the N.H. \& M.R.C. of Australia.

\section{References}

Aldred, L.F. \& Cooke, B.A. (1982) The deleterious effect of mechanical dissociation of rat testis on the functional activity and purification of Leydig cells using Percoll gradients. Int. J. Androl. 5, 191-195.

Christensen, A.K. (1975) Leydig cells. In Handbook of Physiology. Section 7, Endocrinology, Volume 5, Male Reproductive System, pp. 57-94. Eds D. W. Hamilton \& R. O. Greep. American Physiological Society, Washington, D.C.

Cooke, B.A., Magee-Brown, R., Golding, M. \& Dix, C.J. (1981) The heterogeneity of Leydig cells from mouse and rat testes - evidence for a Leydig cell cycle. Int. $J$. Androl. 4, 355-366.

Dehejia, A., Nozu, K., Catt, K.J. \& Dufau, M.L. (1982) Luteinizing hormone receptors and gonadotrophic activation of purified rat Leydig cells. J. biol. Chem. 257, 13781-13786.

Hooker, C.W. (1948) The life history of the interstitial cells of the mouse. Anat. Rec. 100,676-677, Abstr.

Kerr, J.B., Robertson, D.M. \& de Kretser, D.M. (1985) Morphological and functional characterisation of interstitial cells from mouse testes fractionated on Percoll density gradients. Endocrinology 116, 1030-1043.

Laws, A.O., Wreford, N. \& de Kretser, D.M. (1985) Morphological and functional characteristics of rat Leydig cells isolated on Percoll gradients: is Leydig cell heterogeneity in vitro an artifact? Molec. cell. Endocr. (in press).
Lording, D.W. \& de Kretser, D.M. (1972) Comparative ultrastructural and histochemical studies of the interstitial cells of the rat testis during fetal and postnatal development. J. Reprod. Fert. 29, 261-270.

Payne, A.H., Downing, J.R. \& Wong, K.L. (1980) Luteinising hormone receptors and testosterone synthesis in two distinct populations of Leydig cells. Endocrinology 106, $1424-1429$.

Prince, F.P. (1984) Ultrastructure of immature Leydig cells in the human prepubertal testis. Anat. Rec. 209, 165-176.

Risbridger, G.P., Kerr, J.B. \& de Kretser, D.M. (1981) Evaluation of Leydig cell function and gonadotropin binding in unilateral and bilateral cryptorchidism: evidence for local control of Leydig cell function by the seminiferous tubule. Biol. Reprod. 24, 534-540.

Rivarola, M.A., Bergada, C. \& Cullen, M. (1970) HCG stimulation test in prepubertal boys with cryptorchidism in bilateral anorchia and in male pseudohermaphroditism. J. clin. Endocr. Metab. 31, $526-530$.

Roosen-Runge, E.C. \& Anderson, D. (1959) The development of the interstitial cells in the testis of the albino rat. Acta anat. 37, 125-137. 